\title{
Crabs (Brachyura: Grapsoidea: Sesarmidae) as inclusions in Lower Miocene amber from Chiapas, Mexico
}

\author{
María de Lourdes Serrano-Sánchez ${ }^{1}$, Guillermo Guerao², Elena Centeno-García ${ }^{3}$, \\ Francisco J. Vega ${ }^{3, *}$ \\ ${ }^{1}$ Posgrado en Ciencias de La Tierra, Instituto de Geología, UNAM, Ciudad Universitaria, Coyoacán, CDMX, 04510, Mexico. \\ ${ }^{2}$ PS Fabra i Puig 344, 08031-Barcelona, Spain. \\ ${ }^{3}$ Instituto de Geología, UNAM, Ciudad Universitaria, Coyoacán, CDMX, 04510, Mexico. \\ *vegver@unam.mx
}

\begin{abstract}
Nine crab remains preserved in Miocene amber from Chiapas are reported. Systematic affinities of the crab remains indicate that they belong to the Sesarmidae family. Semi-terrestrial sesarmid species are frequently found in mangroves and thus their presence in Lower Miocene (Aquitanian) amber from mines of Campo La Granja, Chiapas reinforce previous interpretations of a mangrove paleoenvironment near the ancient Gulf of Mexico coast.
\end{abstract}

Keywords: Crabs, amber, Miocene, Aquitanian, Chiapas, Mexico.

Resumen

Se reportan nueve restos de cangrejos, preservados en el ámbar del Mioceno de Chiapas. Las afinidades sistemáticas de los restos de cangrejo indican que pertenecen a la familia de los Sesarmidae. Las especies de sesármidos semi-terrestres se encuentran frecuentemente en manglares y por lo tanto, su presencia en el ámbar del Mioceno Inferior (Aquitaniano) de las minas de Campo La Granja, Chiapas, refuerza interpretaciones previas sobre un paleoambiente de manglar, cerca de la antigua costa del Golfo de México.

Palabras clave: Cangrejos, ámbar, Mioceno, Aquitaniano, Chiapas, México.

\section{Introduction}

Crustaceans are found as inclusions in several amber deposits of the world, but decapod crabs are so far know only for the Lower Miocene amber of Chiapas. Before the present contribution, only two specimens have been reported. The first specimen was illustrated by Grimaldi (1996) who indicated grapsoidean affinities for the specimen. In recent studies, Grapsoidea have been subdivided into eight families ( $\mathrm{Ng}$ et al., 2008): Gecarcinidae MacLeay, 1838; Glyptograpsidae Schubart, Cuesta and Felder, 2002; Grapsidae MacLeay, 1838; Percnidae Števčić, 2005;
Plagusiidae Dana, 1851; Sesarmidae Dana, 1851; Varunidae H. Milne Edwards, 1853 and Xenograpsidae Ng, Davie, Schubart and Ng, 2007. Boucot and Poinar (2010) figured the same specimen and suggested a resemblance with the living species Metopaulias depressus Rathbun, 1896 (Sesarmidae). Both Grimaldi (1996) and Boucot and Poinar (2010) speculated on the possible association of this crab with bromeliads. A second specimen was reported by Vega et al. (2009), indicating affinity to the extant genus Sesarma Say, 1817 (Sesarmidae), whose species are frequently found associated to mangrove trees. Eight other crab remains are here reported, all found in amber from Campo La Granja 
mines, north of Simojovel, Chiapas (Figure 1). The nine crab specimens here reported are represented by: thee small complete individuals, two incomplete, tree isolated pereiopods and one endophragmal fragment. It is possible that one of the corpses represents a specimen that was trapped right after the molting process. The carcasses could also be interpreted either as exuviae or decaying corpses in ponds where resin was deposited. Sesarmid crabs are ecologically diverse, living in terrestrial, semi-terrestrial, freshwater, and saltwater environments and include mangrove tree-climbers species (Fratini et al., 2005). A coastal flood-plain with tidal influence in a mangrove system is suggested as the paleoenvironment of deposition for the Lower Miocene amber of Campo La Granja, Chiapas (Serrano-Sánchez et al., 2015).

\section{Stratigraphy and paleoenvironment}

The Chiapas amber is found mainly in the north edge of Chiapas State, Southern Mexico. Three lithostratigraphic units that crop out in this region contain amber, known as (from base to top) La Quinta Formation, Mazantic Shale and Balumtum Sandstone (Allison, 1967; Frost and Langenheim, 1974; Perrilliat et al., 2010; SolórzanoKraemer, 2010; Riquelme et al., 2014) (Figure 2). Amber samples here reported were collected at Campo La Granja mines, which correspond to the upper portion of the La Quinta Formation (Finca Carmitto Member), dated as early Miocene in age (22.8 My, Aquitanian), based on the biostratigraphy of corals, mollusks, microfossils and strontium (Serrano-Sánchez et al., 2015). The amber from Campo La Granja mines is peculiar because of its content of stratified sandstone layers, with unusual contents of mixed association of brackish water, freshwater and terrestrial organisms, mainly arthropods. Amorphous organic matter, decaying plant remains, pyritized ostracods, termites and hemipterans, as well as the presence of psychodid flies (Stebner and Solórzano-Kraemer, 2014), all suggest reducing conditions in the ponds were resin was deposited. Tube-like amber pieces are also found, possibly deposited into decapod galleries. The amber pieces show no evidence of significant transport. The suggested paleoenvironment for the Campo La Granja amber is that of small ponds near an estuary where tides transported sediment and organisms to ponds next to resin-producing trees (Leguminosae) that secreted an extremely fluid resin where aquatic organisms were trapped, but also terrestrial arthropod (arachnids, myriapods and insects) corpses were included (SerranoSánchez et al., 2015).

Due to the poor preservation of the crab specimens, it is difficult to offer an accurate identification, but the remains seem to belong to at least two different sesarmid species.

Specimens are deposited at Museo de Paleontología "Eliseo Palacios Aguilera" (Secretaría de Medio Ambiente e Historia Natural), Calzada de los Hombres Ilustres s/n, Tuxtla Gutiérrez, Chiapas, Mexico, and amber pieces with crab inclusions have the acronym IHNFG (Instituto de Historia Natural, Fósil Geográfico).
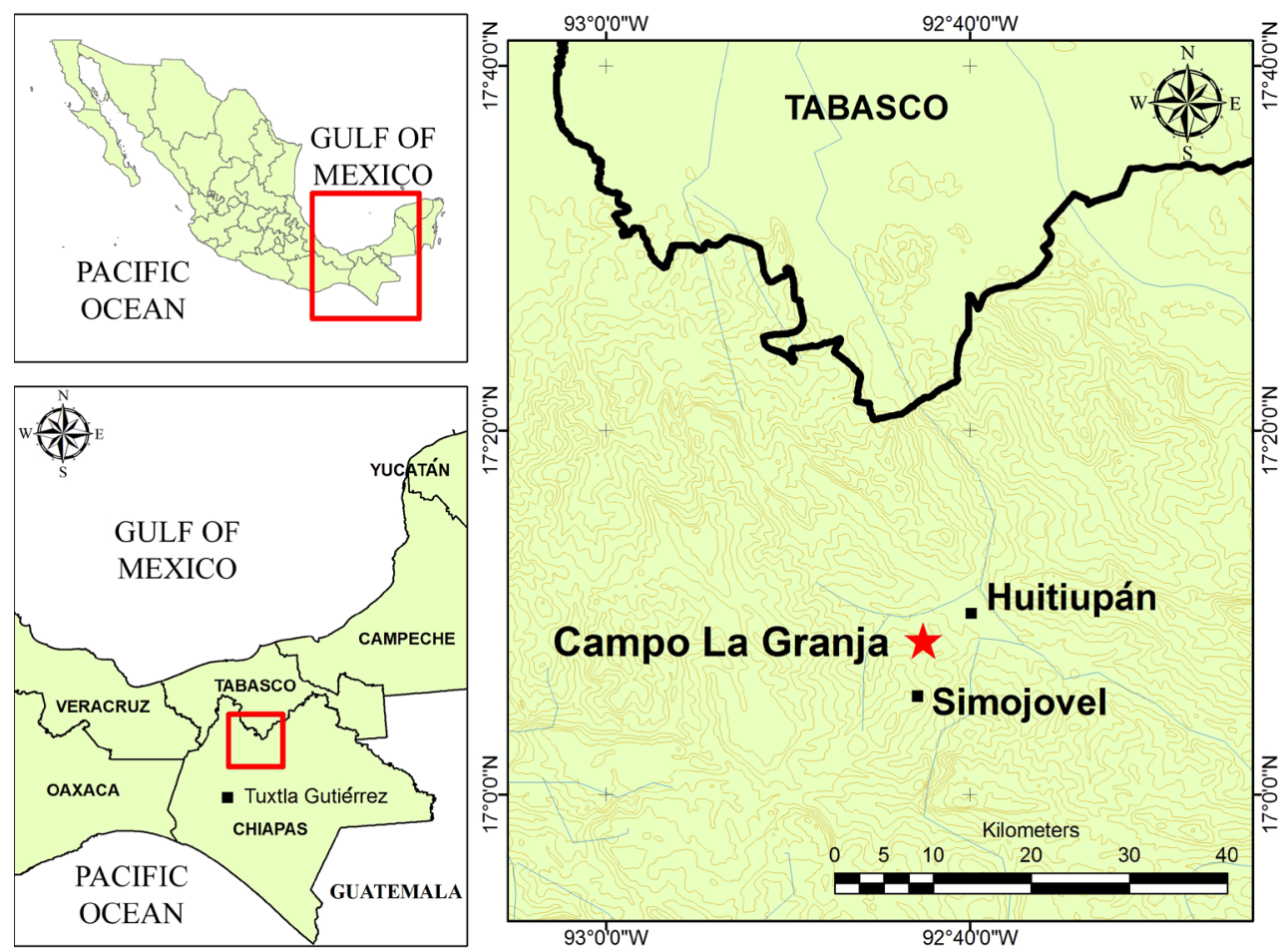

Figure 1. Location map of Campo La Granja mines near Simojovel, Chiapas, Mexico. Modified after Serrano-Sánchez et al., 2015 


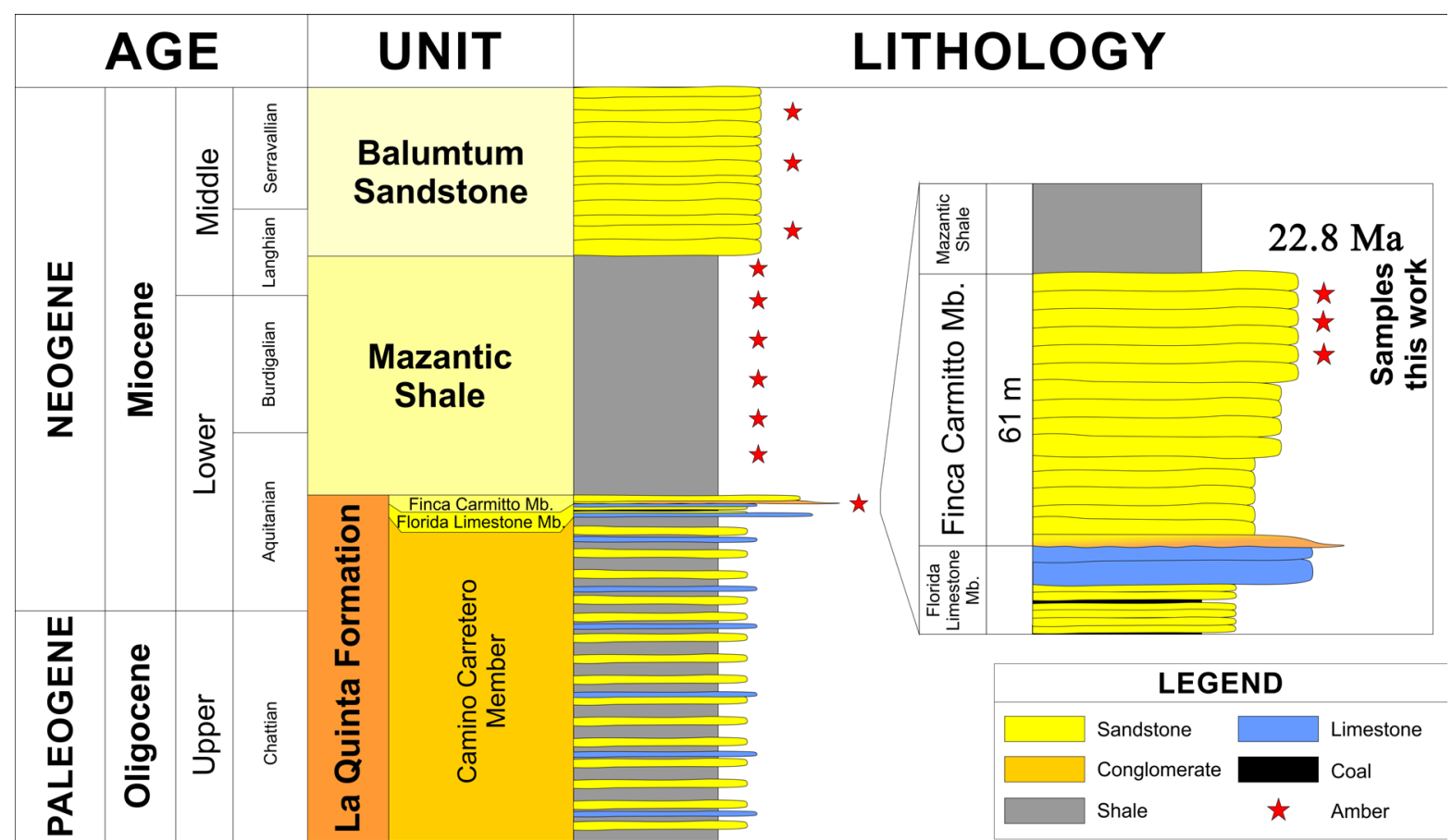

Figure 2. Stratigraphy from the Simojovel area, indicating relative position of Campo La Granja mines. Modified from Allison (1967, figs. 5, 6) and Frost and Langenheim (1974, text-figure 9).

\section{Systematic Paleontology}

Order: Decapoda Latreille, 1793

Infraorder Brachyura Latreille, 1802

Superfamily Grapsoidea MacLeay, 1838

Family: Sesarmidae Dana, 1851

Figs. 3,4

Description of specimens. Cephalothorax small (width of cephalothorax between 1 to $6 \mathrm{~mm}$ ), wider than long, with prominent, large eyes; dorsal cephalothorax regions rugose, poorly defined, covered by sediment and/or fragments of molted cuticle; front of cephalothorax straight, wide, being about $3 / 4$ of the maximum cephalothorax width; eyes prominent, globose, projected beyond orbits; orbits wide; anterolateral margin smooth, curved; posterolateral margin short, about $1 / 3$ the maximum cephalothorax length, curved; posterior margin straight, nearly $2 / 3$ the maximum cephalothorax width; pterygostomial region of specimen IHNFG-4992 with a network-like reticulated pattern (distinguishing feature of Sesarmidae, Fig. 3.11, 4.1, 4.2 ); thoracic sternum subquadrate; third maxillipeds elongate, suboval; left cheliped slightly larger than right cheliped, carpus robust, palm subrectangular; fixed finger short, acute, nearly straight; movable finger curved, acute; pereiopods 2-5 long, slender, merus long, tubular; carpus similar to merus but $1 / 3$ its length; propodus slender, half the length of merus; dactylus long, acute, $2 / 3$ length of propodus; pleon triangular; pleonite 5 subrectangular, $1 / 6$ the maximum cephalothorax width, $1 / 8$ length; telson triangular, slightly narrower than somite 5 but subequal length.

Discussion of specimens. Grimaldi (1996), Vega et al. (2009) and Boucot and Poinar (2010) agree on the grapsoidean affinity of the crabs preserved in Mexican amber. Boucot and Poinar (2010) suggested affinity of the first figured crab with Metopaulias depressus. Comparing the illustrations of that specimen by Grimaldi (1996, p. 66) and Boucot and Poinar (2010, p. 351, fig. A23), it seems that at least one corpse here reported is similar (Fig. 3.1). However, although $M$. depressus is a small crab too (less than $20 \mathrm{~mm}$ in cephalothorax width), it is found nowadays inland, usually above $300 \mathrm{~m}$, associated exclusively to the water-storing leaf axils of bromeliad plants in Jamaica. The bromeliads provide a supporting microclimate, safety, food, and are expandable and defendable resources (Hartnoll, 1964; 1988; Diesel and Schubart, 2007). The paleoenvironment interpreted for the Campo La Granja amber is that of small temporary ponds, controlled by tidal and fluvial influence. The association of crab remains with brackish water copepods and ostracods makes it improbable that the crabs were living in bromeliads. The cephalothorax of $M$. depressus is different from the Mexican amber specimens in having more defined cephalothorax regions, more robust, nearly equal chelipeds and proportionally longer merus of pereiopods 2-5.

Vega et al. (2009) suggested affinities of the second specimen (Fig. 3.1-3.5) to Sesarma Say, 1817. There are two fossil species of Sesarma known so far: S. paraensis Beurlen, 1958, from the Lower Miocene of Pará, Brazil (de Araújo- 

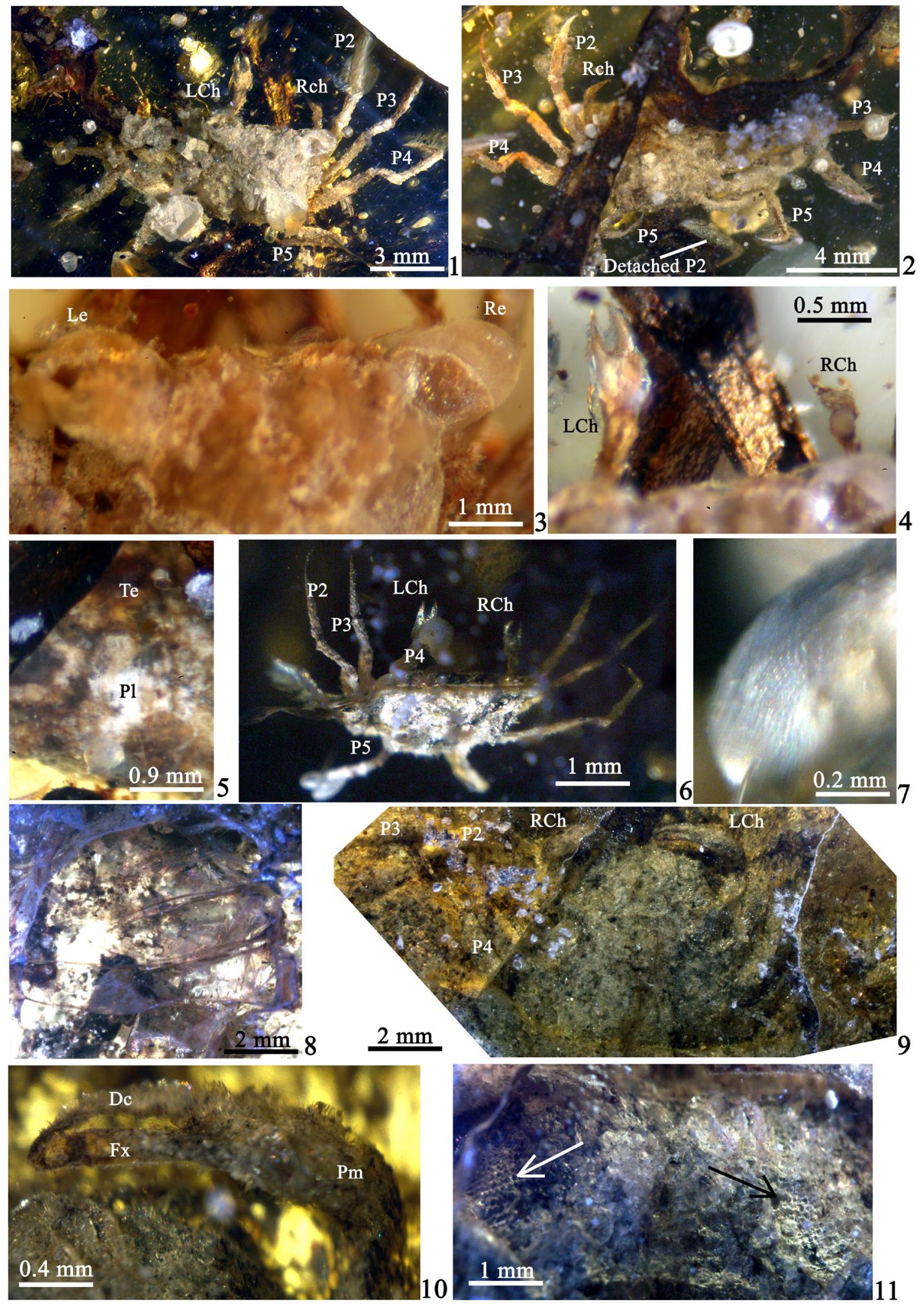

Figure 3. Sesarmidae. 1, Dorsal view of cephalothorax, specimen IHNFG-4991. 2, Ventral view of cephalothorax, same specimen. 3, Detail of front, same specimen. 4, Detail of chelipeds, same specimen. 5, Detail of sternum, same specimen. 6, Frontal view of cephalothorax, specimen IHNFG-5555. 7, Detail of left eye, same specimen. 8, Endophragmal fragment, specimen IHNFG-5316. 9, Ventral view of cephalothorax, specimen IHNFG-4992. 10, Detail of left chela, same specimen. 11, Detail of the network-like reticulated pattern (arrows) on pterygostomial region, same specimen. Abbreviations: $\mathrm{Dc}=$ dactylus, $\mathrm{Fx}=$ fixed finger, $\mathrm{LCh}=$ left cheliped, $\mathrm{Le}=$ left eye, $\mathrm{P} 2-\mathrm{P} 5=$ pereiopods, $\mathrm{Pl}=$ pleon, $\mathrm{RCh}=$ right cheliped, $\mathrm{Re}=$ right eye, $\mathrm{Te}=$ telson. 

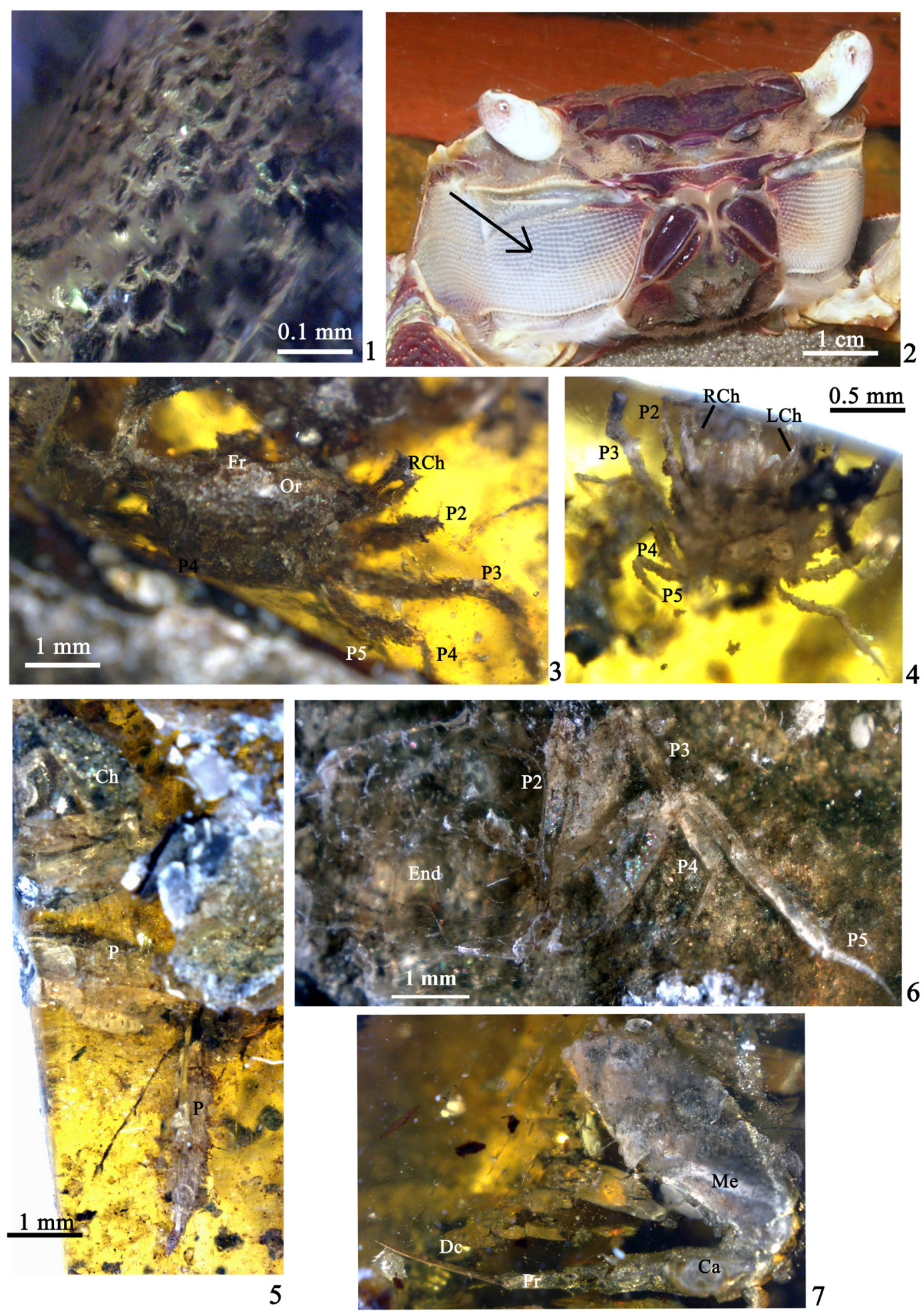

Figure 4. Sesarmidae. 1, Detail of the network-like reticulated pattern on right side of pterygostomial region, specimen IHNFG-4992. 2, Detail of the network-like reticulated pattern (arrow) on right side of pterygostomial region of a living specimen of Pseudosesarma bocourti (A. Milne-Edwards, 1869). 3, Frontal view of cephalothorax, specimen IHNFG-4969. 4, Ventral view of cephalothorax, specimen IHNFG-4970. 5, Isolated cheliped and pereiopods, specimen IHNFG-4912. 6, Isolated pereiopods, specimen IHNFG-4929. 7, Isolated pereiopod, specimen IHNFG-4993. Abbreviations: Ca $=$ carpus, Ch $=$ cheliped, $\mathrm{Dc}=$ dactylus, End $=$ endophragma, $\mathrm{Fr}=$ frontal margin of cephalothorax, $\mathrm{Fx}=$ fixed finger, $\mathrm{LCh}=$ left cheliped, $\mathrm{Le}=$ left eye, $\mathrm{Me}=$ merus, $\mathrm{Or}=$ eye orbit, $\mathrm{P}=$ pereiopod, $\mathrm{P} 2-\mathrm{P} 5=$ pereiopods, $\mathrm{Pr}=$ propodus, $\mathrm{RCh}=$ right cheliped. 
Távora et al., 2010) and S. primigenium Collins, Mitchell and Donovan, 2009, from the Pleistocene of Jamaica. The first was described based on a single cephalothorax (25 $\mathrm{mm}$ ), while the second was described based on small chelae fragments. There are also similarities between the crabs in Mexican amber and the genus Armases Abele, 1992. Species of Armases tend to be wider than long, have more slender pereiopods than Sesarma spp., but no diagnostic features were preserved in order to offer a more precise identification for the specimens, beyond the family level.

Based on size ( 0.5 to $2 \mathrm{~mm}$ cephalothorax width) of the three corpses here reported (Figs. 3.1-3.5, 3.6-3.8, 4.4), it seem that the specimens got trapped into the resin as juveniles (Anger et al., 1995; Guerao et al., 2007).

Since the crab remains are found in pieces containing also brackish water crustaceans, it is possible that the crabs were carried to the ponds of the flood-plain by tides, where they either died or were already dead when transported.

\section{Conclusions}

The nine remains here reported belong to sesarmid crabs, representing corpses and detached appendages. Two specimens were probably alive when they were trapped into the resin; one of them preserves a detached pereiopod, possibly as autotomy resulting of the trapping in the sticky resin. The other remains represent corpses and detached appendages. Based on shape of amber pieces, sedimentological evidences and nature of inclusions, ponds in tidal flat mangrove environment is suggested as the resin deposit scenario for Campo La Granja amber, 22.8 Ma ago. Although crabs are relatively scarce when compared with other crustaceans (ostracods, copepods, tanidaceans, amphipods, isopods), they are an important addition to the knowledge of semi-terrestrial crustaceans and the paleoenvironment of deposition of Mexican amber.

\section{Acknowledgements}

Our sincere gratitude to Peter $\mathrm{Ng}$, Gérard Breton and an anonymous reviewer for their criticism and suggestions to improve the original version of the manuscript. Thanks to Gerardo Carbot, Jorge Balcázar and Marco Coutiño for assistance in the field and museum.

\section{References}

Abele, L.G., 1992, A review of the grapsid crab genus Sesarma (Crustacea: Decapoda: Grapsidae) in America, with the description of a new genus: Smithsonian Contributions to Zoology, 527, 1-60.

Allison, R.C., 1967, The Cenozoic stratigraphy of Chiapas, México, with discussions of the classification of the Turritellidae and selected Mexican representatives: Ph.D. dissertation, University of California, Berkeley, 225 p.
Anger, K., Schreiber, D., Montú, M., 1995, Abbreviated larval development of Sesarma curacaoense (Rathbun, 1897) (Decapoda: Grapsidae) reared in the laboratory: Nauplius, Rio Grande, 3, 127-154.

Araújo-Távora, V. de, Rodrigues-dos Santos, A.A., Neto-Araújo, R., 2010, Localidades fossilíferas da Formação Pirabas (Mioceno Inferior): Boletim do Museu Paraense Emílio Goeldi, Ciências Naturais, Belém, 5, 2, 207-224.

Beurlen, K., 1958, Contribuição à paleontologia do estado do Pará: Crustáceos Decápodos da Formação Pirabas. Boletim do Museu Paraense Emilio Goeldi, (nova série) (Geologia), 5, 1-48.

Boucot, A.J., Poinar, G.O., Jr., 2010, Fossil Behavior Compendium, Boca Raton: CRC Press, $391 \mathrm{p}$.

Collins, J.S.H., Mitchell, S.F., Donovan, S.K., 2009, A new species of land crab, Sesarma Say, 1817 (Decapoda, Brachyura), from the Pleistocene of Jamaica: Scripta Geologica, 138, 11-21.

Dana, J.D., 1851, Crustacea Grapsoidea, (Cyclometopa, Edwardsii). Conspectus Crustaceorum quae in Orbis Terrarum circumnavigatione, Carolo Wilkes e Classe Reipublicae Foederatae duce, lexit et descripsit, 8: Proceedings of the Academy of Natural Sciences of Philadelphia, 5, 247-254.

Diesel, R., Schubart, C.D., 2007, The social breeding system of the Jamaican bromeliads crab, Metopaulias depressus, in Duffy, J.E., Thiel, M. (eds.), Evolutionary ecology of social and sexual systems: Crustacea as model organisms, Oxford University Press, 365-386.

Fratini, S., Vannini, M., Cannicci, S., Schubart, C.D., 2005, Tree-climbing mangrove crabs: a case of convergent evolution: Evolutionary Ecology Research, 7, 219-233.

Frost, S.H., Langenheim, R.L., 1974, Cenozoic reef biofacies, Tertiary larger Foraminifera and scleractinian corals from Chiapas, Mexico. De Kalb (IL): Northern Illinois University Press. 388 p.

Grimaldi, D.A., 1996, Amber: Window to the Past: Harry N. Abrams/ American Museum of Natural History, New York, $216 \mathrm{p}$.

Guerao, G., Anger, K., Schubart, C.D., 2007, Larvae and first-stage juveniles of the American genus Armases Abele, 1992 (Brachyura: Sesarmidae): a morphological description of two complete developments and one first zoeal stage: Journal of Natural History, 41, 29/32, 1811-1839.

Hartnoll, R.G., 1964, Two cavernicolous decapods from Jamaica: Crustaceana, Leiden, 7, 1, 78-79.

Hartnoll, R.G., 1988, Evolution, systematics, and geographical distribution, in Burggren, W.W., McMahon, B.R. (eds.), Biology of the land crabs, Cambridge University Press, 6-54.

Latreille, P.A., 1802-1803, Histoire naturelle, générale et particulière, des Crustacés et des Insectes, 3, 1-468. (F. Dufart, Paris).

MacLeay, W.S., 1838, On the brachyurous decapod Crustacea brought from the Cape by Dr. Smith. in A. SMITH, Illustrations of the Annulosa of South Africa; consisting chiefly of figures and descriptions of the objects of natural history collected during an expedition into the interior of South Africa, in the years 1834, 1835, and 1836; fitted out by "The Cape of Good Hope Association for Exploring Central Africa": 53-71, 2 pls. (Smith, Elder and Company, London).

Milne Edwards, A., 1869, Notes sur quelques nouvelles especes du genre Sesarma (Say): Nouvelles Archives du Muséum d'Histoire Naturelle, Paris, 5: 25-31.

Milne Edwards, H., 1853, Mémoire sur la famille des Ocypodides. Suite (1). Deuxième Tribu Principale: Annales des Sciences Naturelles, 3e série 20, 163-228.

Ng, N.K., Davie, P.J.F., Schubart, C.D., Ng, P.K.L., 2007, Xenograpsidae, a new family of grapsoid crabs (Crustacea: Brachyura) associated with shallow water hydrothermal vents: The Raffles Bulletin of Zoology, Supplement 16, 233-256.

Ng, P.K.L., Guinot, D., Davie, P.J.F., 2008, Systema Brachyurorum: Part I. An annotated checklist of extant brachyuran crabs of the world: Raffles Bulletin of Zoology, Supplement 17, 1-286.

Perrilliat, M., Vega, F., Coutiño, M., 2010, Miocene mollusks from the Simojovel area in Chiapas, southwestern Mexico: Journal of South American Earth Sciences, 30, 111-119.

Rathbun, M.J., 1896, Description of a new genus and four new species of crabs from the West Indies: Proceedings of the United States National 
Museum, 19, 1104, 141-144.

Riquelme, F., Alvarado-Ortega, J., Ramos-Arias, M., Hernández, M., Le Dez, I., Lee-Whitingd, T.A., Ruvalcaba-Sil, J.L., 2014, A fossil stemmiulid millipede (Diplopoda: Stemmiulida) from the Miocene amber of Simojovel, Chiapas, México: Historical Biology, 26, 415-427.

Say, T., 1817-1818, An Account of the Crustacea of the United States. Journal of the Academy of Natural Sciences of Philadelphia, 1(12):57-63, 65-80 (plate 4), 97-101, 155-160, 161-169 [all 1817], 235-253, 313-319, 374-380, 381-401, 423-441 [all 1818]. [See Holthuis, 1969: vi, vii, for dates of publication.]

Schubart, C.D., Cuesta, J.A., Felder, D.L., 2002, Glyptograpsidae, a new brachyuran family from Central America: larval and adult morphology, and a molecular phylogeny of the Grapsoidea. Journal of Crustacean Biology, 22, 28-44.

Serrano-Sánchez, M.L., Hegna, T.A., Schaaf, P., Centeno-García, E., Pérez, L., Vega, F.J., 2015, The aquatic and semiaquatic biota in Miocene amber from the Campo La Granja mine (Chiapas, Mexico): paleoenvironmental implications: Journal of South American Earth Sciences, 62, 243-256.
Solórzano-Kraemer, M.M., 2010, Mexican amber, in Penney, D. (ed.), Biodiversity of Fossils in Amber from the Major World Deposits. Manchester, Siri Scientific Press, 42-56.

Stebner, F., Solórzano-Kraemer, M.M., 2014, Systematic and palaeoecology of Psychodidae (Insecta: Diptera) from Miocene Mexican amber: Palaeontographica, Abteilung A, 303, 1/3, 1-21.

Števčić, Z., 2005, The reclassification of brachyuran crabs (Crustacea: Decapoda: Brachyura): Natura Croatica, 14, Supplement 1, 1-159.

Vega, F.J., Zúñiga, L., Pimentel, F., 2009, First formal report of a crab in amber from the Miocene of Chiapas and other uncommon Crustacea: Geological Society of America, Abstracts with Programs, 41, 7, 631.

Manuscript received: May 7, 2015

Corrected manuscript received: June 10, 2015

Manuscript accepted: June 12, 2015 